\title{
Severe Diabetic ketoacidosis in a Newly Diagnosed Child with Type 2 Diabetes Mellitus: A Case Report
}

\author{
Abdulmoein E Al-Agha ${ }^{1^{*}}$ and Mohammed A Al-Agha ${ }^{2}$ \\ ${ }^{1}$ Department of Pediatric Endocrinology King Abdul-Aziz University Hospital, Saudi Arabia \\ ${ }^{2}$ Faculty of Medicine, King Abdul-Aziz University, Saudi Arabia
}

"Correspondence author: Abdulmoein E Al-Agha, Professor of Pediatric Endocrinology, Pediatric Department, King Abdul-Aziz University Hospital, P.O. Box 80215, Jeddah 21589, Saudi Arabia, Tel: 0505590459; Fax: + 9662640 3841, + 9662 6408353; E-mail: aagha@kau.edu.sa

Received date: January 01, 2017; Accepted date: February 14, 2017; Published date: February 20, 2017

Copyright: ( 2017 Al-Agha AE, et al. This is an open-access article distributed under the terms of the Creative Commons Attribution License, which permits unrestricted use, distribution, and reproduction in any medium, provided the original author and source are credited.

\begin{abstract}
Background: Diabetes ketoacidosis (DKA) is an acute complication of both type 1 and type 2 diabetes mellitus (DM). DKA is characterized by the presence of hyperglycemia, ketosis, ketonuria, and metabolic acidosis. Cerebral edema is a rare but rather a serious complication of DKA.
\end{abstract}

Case presentation: An obese 12-year-old, Egyptian boy, previously medically free, presented to the emergency room (ER) of King Abdulaziz university hospital, with two weeks' histories of dizziness, shortness of breath, polyuria, polydipsia \& nocturia. His symptoms were deteriorating with a change in sensorial and cognitive functions at the time of presentation. He was diagnosed with type $2 \mathrm{DM}$ based upon clinical background, namely the presence of obesity (weight+7.57 Standard Deviation Score (SDS), height+1.4 SDS, and body mass index (BMI) of $34.77 \mathrm{~kg} / \mathrm{m}^{2}$ $(+3.97 \mathrm{SDS})$ together with the presence of Acanthosis nigricans and biochemically based on, normal level of serum insulin, normal serum level of connecting peptide and negative autoantibodies. He was presented with severe DKA, based on clinical and laboratory criteria. During the first $12 \mathrm{~h}$ of hospitalization, the patient has developed cerebral edema based upon clinical and radiological bases with the requirement of intensive therapeutically managements with final complete clinical, biochemical and radiological recovery. The patient was discharged home on oral metformin therapy after gradual weaning from insulin therapy, which was needed initially during his acute presentation. We aimed to present a rare presentation of severe DKA with cerebral edema in a child with Type 2 DM.

Conclusion: Despite type $1 \mathrm{DM}$ is the commonest type of diabetes in children, pediatricians should be aware of other types of diabetes, particularly type 2, as the prevalence of obesity in children is increasing. Children with type 2 DM are also prone to develop DKA, thus proper and rapid investigations to diagnose DKA in suspected patients are mandatory. Those patients are also at risk to develop cerebral edema, thus proper monitoring for neurological symptoms during the management of DKA is crucial.

Keywords: Type 2 Diabetes; ketoacidosis; Complication; Cerebraedema

\section{Introduction}

Diabetes mellitus (DM) is a chronic metabolic disease that affects carbohydrate, fat and protein metabolism [1]. Various types of DM could affect children, including type 1 diabetes mellitus (T1DM), type2 diabetes mellitus (T2DM), Maturity Onset Diabetes of the Young (MODY), and neonatal diabetes (NDM) [2]. The commonest type among children is type 1 ; however, type 2 incidence is remarkably increasing, which is probably related to increasing obesity among children [3-5]. Type 2 Diabetes mellitus (T2DM) usually affects obese children and adults, especially those having a positive family history. T2DM is characterized by the presence of hyperglycemia with high or normal insulin secretion from the beta cells of the pancreas at early stages of the disease labeled as "insulin receptor resistance" with gradual loss of insulin production with time [6-10]. Patients usually present with milder symptoms of polyuria, polydipsia, polyphagia and loss of weight in comparison to T1DM [11]. Diabetic ketoacidosis (DKA) is characterized by the presence of hyperglycemia, ketosis with ketonuria, and metabolic acidosis. DKA is a common acute complication of T1DM, but could also happen in T2DM. Hyperosmolar hyperglycemic non-ketotic coma is another acute complication of T2DM [12]. Cerebral edema is an uncommon but rather a serious consequence of DKA [13]. It could develop spontaneously or during treatment of DKA, especially during the first 4 to $12 \mathrm{~h}$ of initiation of treatment, but still could occur up to $24 \mathrm{~h}$ of initiation of treatment [14]. It rarely occurs before initiation of treatment or after $24 \mathrm{~h}$ of initiation of treatment. Usually headache, dizziness, agitation are the earliest signs, but other symptoms such as altered level of consciousness, age-inappropriate incontinence or sustained heart rate deceleration are early symptoms that often appears even before remarkably changes on brain computed tomography (CT) [15]. We aimed to report 12 y old, obese child presented with type 2 DM associated with severe metabolic acidosis of DKA and cerebral edema.

\section{Case Report}

An obese 12 y old Egyptian boy, previously medically free, presented to the emergency room (ER) of King Abdulaziz university hospital, 
Citation: Abdulmoein E Al-Agha1, Mohammed A Al-Agha (2017) Severe Diabetic ketoacidosis in a Newly Diagnosed Child with Type 2 Diabetes

Page 2 of 4

with two weeks' histories of, shortness of breath, polyuria, polydipsia \& nocturia and mild weight loss. He was in his usual health state until 14 days' prior of presentation, when he started to have loss of appetite, fatigability, polyuria, polydipsia \& nocturia that waked him up to 6 times per night. He also had palpitations, non-bilious vomiting, with moderate generalized abdominal pain. Initially, there were no histories of a headache, seizures, irritability, loss of consciousness, fever, cough, chest pain, joint pain or skin rash. Unfortunately, his family has not brought him till lately, when his symptoms were deteriorating with a headache; dizziness, agitation and altered level of consciousness with changes in sensorial and cognitive functions were all present at the time of presentation. His nutritional history was of unhealthy "junk" food with no regular exercise "sedentary lifestyle". He had no other remarkable past medical or surgical histories. His family history revealed, no parental consanguinity, but a positive family history of obesity in parents, his grandfather and many family members have type 2 diabetes. His initial examination revealed severely dehydrated with Kussmaul breathing. Vital signs were the temperature of $36.8^{\circ} \mathrm{C}$, heart rate of 124 beats/min, high blood pressure of $175 / 100$, respiratory rate of $30 / \mathrm{min}$ with peripheral oxygen saturation of $98 \%$. Weight was $89 \mathrm{~kg}$ (+7.57 Standard Deviation Score (SDS)), height was $160 \mathrm{~cm}\left(+1.4\right.$ SDS), and body mass index (BMI) of $34.77 \mathrm{~kg} / \mathrm{m}^{2}(+3.97$ SDS). Neurologicallyn he was agitated with frequent attempts of removing the intravenous cannula, confused, talking with inappropriate words, not age matched. Glasgow coma scale (GCS) of $13 / 15$, normal tone and reflexes. He also had acanthosis nigricans at his neck and thigh folds (Figure 1). His first few hours after admission to the pediatric intensive unit, he became disoriented, GCS deteriorated down to $8 / 15$, with bilaterally reactive pupils, no gag reflex, $\mathrm{O}_{2}$ saturation started to drop down to $84 \%$ on room air, for which patient was ventilated electively (Table 1 ).

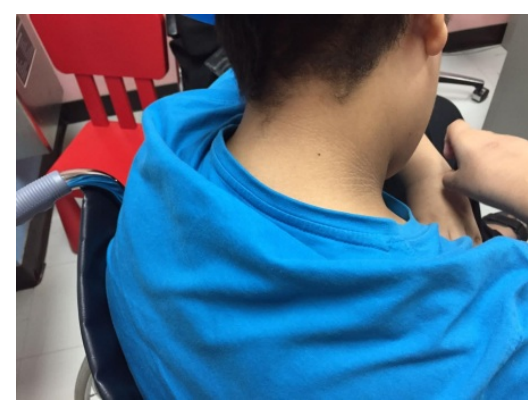

Figure 1: Acanthosis Nigricans on the neck of an obese $12 \mathrm{y}$ old patient with newly diagnosed type 2 diabetes mellitus.

\begin{tabular}{|l|l|l|l|l|}
\hline & $\begin{array}{l}\text { At } \\
\text { presentati } \\
\text { on }\end{array}$ & $\begin{array}{l}\text { During few } \\
\text { hours on } \\
\text { admission }\end{array}$ & $\begin{array}{l}\text { On } \\
\text { discharg } \\
\text { e }\end{array}$ & $\begin{array}{l}\text { Normal } \\
\text { range }\end{array}$ \\
\hline $\mathrm{PH}$ & 6.997 & 7.02 & 7.40 & $7.37-7.45$ \\
\hline $\begin{array}{l}\text { Serum } \\
\text { bicarbonate1 }\end{array}$ & 7.2 & 6.4 & 23 & $21-26$ \\
\hline Base excess1 & -26 & -20 & -2 & UP TO 2 \\
\hline O2 sat \% & 98 & 84 & 99 & $94-100$ \\
\hline $\begin{array}{l}\text { Random Blood } \\
\text { glucose1 }\end{array}$ & 27 & 18 & 8 & $3.9-6.7$ \\
\hline
\end{tabular}

\begin{tabular}{|c|c|c|c|c|}
\hline Urine ketone & +3 & +2 & negative & negative \\
\hline Serum sodium1 & 129 & 150 & 143 & $136-145$ \\
\hline Serum potassium1 & 3.4 & 4.4 & 3.8 & $3.5-5.1$ \\
\hline Serum chloride 1 & 101 & 102 & 102 & $98-107$ \\
\hline Serum Urea1 & 12.3 & 5.8 & 3.7 & $2.5-6.4$ \\
\hline Serum Creatinine2 & 140 & 87 & 80 & $53-115$ \\
\hline $\mathrm{HbA} 1 \mathrm{C}$ & \multicolumn{3}{|l|}{$10.72 \%$} & $4.2-6.3 \%$ \\
\hline Serum Phosphate1 & 0.71 & 0.82 & 1.27 & $0.8-1.58$ \\
\hline Serum Albumin3 & 43 & 40 & 42 & $40.2-47.6$ \\
\hline $\begin{array}{l}\text { Serum } \\
\text { magnesium1 }\end{array}$ & 1.05 & 1.02 & 0.87 & $0.70-1$ \\
\hline Cortisol7 & 439 & & & $118.60-618$ \\
\hline $\begin{array}{l}\text { Insulin like Growth } \\
\text { Factor } 1 \text { (IGF1)14 }\end{array}$ & 192 & & & $143-693$ \\
\hline Testosterone7 & 12.6 & & & $8.4-28.7$ \\
\hline $\begin{array}{l}\text { White blood cell } \\
\text { count (WBC)9 }\end{array}$ & 9.9 & & 7.86 & $4.5-13.5$ \\
\hline $\begin{array}{l}\text { Red blood cell } \\
\text { count }(\mathrm{RBC}) 10\end{array}$ & 6.44 & & 2.93 & $4-5.40$ \\
\hline Hemoglobin $(\mathrm{Hb}) 11$ & 15.9 & & 7.1 & $12-15$ \\
\hline $\begin{array}{l}\text { Hematocrit } \\
\%\end{array}$ & 46.3 & & 22.1 & $35-49$ \\
\hline $\begin{array}{l}\text { Mean cell volume } \\
(\mathrm{MCV}) 12\end{array}$ & 71.9 & & 75.4 & $80-94$ \\
\hline $\begin{array}{l}\text { Mean cell } \\
\text { hemoglobin } \\
(\mathrm{MCH}) 13\end{array}$ & 24.7 & & 24.2 & $32-36$ \\
\hline Platelets (PLT)9 & 350 & & 388 & $150-450$ \\
\hline $\begin{array}{l}\text { Thyroid stimulating } \\
\text { hormone } 4\end{array}$ & 1.37 & & & $0.27-4.2$ \\
\hline Free Thyroxin5 & 15 & & & $12-22$ \\
\hline Insulin6 & 5.41 & & & $2.60-37.60$ \\
\hline $\begin{array}{l}\text { Connecting } \\
\text { peptide7 }\end{array}$ & 0.438 & & & $0.16-1.68$ \\
\hline Lactic acid & 1.2 & 1.2 & 1.2 & $0.4-2$ \\
\hline Amylase8 & 29 & 29 & 29 & $25-115$ \\
\hline Lipase8 & 388 & 388 & 388 & 73-393 \\
\hline Serum Calcium1 & 2.42 & 2.39 & 2.40 & $2.12-2.52$ \\
\hline $\begin{array}{l}\text { Islet Cell } \\
\text { Autoantibodies }\end{array}$ & Negative & & & \\
\hline $\begin{array}{l}\text { Glutamic Acid } \\
\text { Decarboxylase } \\
\text { Autoantibodies }\end{array}$ & Negative & & & \\
\hline
\end{tabular}


Table 1: 1: (mmol/L); 2: ( $\mu \mathrm{mol} / \mathrm{L}) ; 3:(\mathrm{g} / \mathrm{L}) ; 4:(\mu \mathrm{IU} / \mathrm{L}) ; 5:(\mathrm{Pmol} / \mathrm{L}) ; 6:$ (mIU/L); 7: (nmol/L); 8: ( U/L); 9: (K/uL); 10: (M/uL); 11: (g/dL); 12: (fL); 13: (pg); 14: (ng/mL).

\section{Discussion}

The present report described a newly-onset type 2 DM with severe DKA that has developed cerebral edema within few hours after hospital admission. Clinical features were suggestive, the diagnosis of type $2 \mathrm{DM}$ including, obesity, acanthosis nigricans, and a family history of type $2 \mathrm{DM}$ were present, pancreatic autoantibodies that characterize type $1 \mathrm{DM}$ namely (Islet Cell Autoantibodies, Glutamic Acid Decarboxylase Autoantibodies, and Insulin Autoantibodies) were all negative. Acanthosis nigricans, which is a thickened darkish discoloration of the skin, that could be either inherited or acquired due to obesity or endocrine causes especially diseases in which there is insulin resistance such as type $2 \mathrm{DM}$, Cushing disease, and acromegaly. In the present case, there is no familial cause of acanthosis nigricans, no dysmorphic features, and neither clinical features nor laboratory investigations that support an endocrine cause, other than type $2 \mathrm{DM}$ were present. Random serum insulin and connecting peptide levels were normal prior to start exogenous insulin. Management of DKA was started immediately after presentation according to ISPAD Clinical Practice Consensus Guidelines 2014. Goals of management of DKA are to correct the dehydration and the acidosis while reversing the ketosis, slowly correcting the hyperosmolarity and to restore the blood glucose to near normal values. Continuous monitoring for complications of DKA and its management is crucial. The patient was first started on fluid replacement with normal saline, as a bolus at the beginning, and then continued on maintenance plus remaining deficit (over $48 \mathrm{~h}$ ), while taking into account that the rate of infusion does not exceed 1.5-2 times the usual daily maintenance requirement. Potassium chloride (KCL) with $40 \mathrm{mmol}$ potassium/L was added in the infusate at the same time of starting intravenous insulin, with ECG monitoring and after assessment of the existence of normal urine output. After one hour, the patient was started on intravenous insulin (0.1 unit $/ \mathrm{kg} / \mathrm{h}$ ), while bicarbonate was never part of the management. Ten hours, post admission, he became disoriented, with agitated behavior, frequent attempts of removing the intravenous cannula, confused, talking with inappropriate words, not age-matched with Glasgow coma scale (GCS) deteriorated down to 8/15, with bilaterally reactive pupils and no gag reflex. After excluding hypoglycemia as being the cause of those new symptoms, management of cerebral edema was started immediately. The patient was ventilated electively, has received a stat dose of mannitol $0.5 \mathrm{~g} / \mathrm{kg}$ intravenously (IV) (total of $40 \mathrm{~g}$ ) over $30 \mathrm{~min}$, with the restriction of the IV fluid to correct the deficit over $72 \mathrm{~h}$. Brain CT scan showed radiological changes were consistent with cerebral edema. Six days' post admission; patient had a complete recovery from both DKA and cerebral edema, and then was transferred to the pediatric medical ward. Finally, the patient was discharged home on oral metformin therapy after gradual weaning off from insulin therapy, which was needed initially during his acute presentation. Initial alterations in the renal function were due to dehydration, which was improved completely with rehydration, that's why no further investigations were needed, and renal Ultrasound was normal.
The literature review revealed that DKA could occur in patients with T2DM, but usually at a higher blood glucose level than in DKA patients with T1DM. This was the result of a retrospective review in a tertiary center of 69 patients (between 9 and 18 years of age) who presented with DKA, of which $13 \%$ had type 2 diabetes mellitus [16]. In another retrospective review of 100 patients, 50 of which had T2DM \& the other 50 had T1DM, that aimed to compare the characteristics of youth patients with those types of DM at diagnosis, $>25 \%$ of type 2 DM had DKA. The study also revealed increased prevalence of obesity, acanthosis nigricans, and hypertension among patients with type 2 DM [17]. Regarding cerebral edema development in DKA patients, a retrospective study that aimed to assess the risk factors for cerebral edema of 61 children with DKA \& in whom has developed cerebral edema, has found that children who had low partial pressures of arterial carbon dioxide $\left(\mathrm{PaCO}^{2}\right)$ and high serum urea nitrogen concentrations at presentation and who were treated with bicarbonate were at increased risk for cerebral edema [18]. Although some theories have been suggested to be the cause of developing cerebral edema, even with the best application of guidelines, cerebral edema still can occur, thus the best way to prevent it is by preventing the development of DKA [14]. We have reported this case to enrich the knowledge of pediatricians to consider the possibility of type $2 \mathrm{DM}$ in obese children and adolescent presented with DKA. As most of physicians, when they face a child with severe DKA consider type1 DM while in this case severe DKA was a presentation of type 2 DM.

\section{Conclusion}

Early presentation of children and adolescent with diabetes is crucial to prevent acute complication such as diabetic ketoacidosis. Community awareness of signs and symptoms of diabetes has to be raised up through educational programs, diabetes awareness campaign and school educational tutorials.

\section{References}

1. American Diabetes Association (2010) Diagnosis and classification of diabetes mellitus. Diabetes Care 33: S62-S69.

2. David M, McCulloch K (2016) Classification of diabetes mellitus and genetic diabetic syndrome. Genetic diabetic syndromes 2: 51-82.

3. Fagot-Campagna A (2000) Type 2 diabetes among North American children and adolescents: an epidemiologic review and a public health perspective. J Pediatr 136: 664-672.

4. Lipton RB (2005) Obesity at the onset of diabetes in an ethnically diverse population of children: what does it mean for epidemiologists and clinicians? Pediatr 115: e553-e560.

5. SEARCH for Diabetes in Youth Study Group (2006) The burden of diabetes mellitus among US youth: prevalence estimates from the SEARCH for Diabetes in Youth Study. Pediatr 118: 1510-1518.

6. Beck-Nielsen H, Groop LC (1994) Metabolic and genetic characterization of prediabetic states. Sequence of events leading to non-insulindependent diabetes mellitus. J Clinl Invest 94: 1714-1721.

7. Kahn CR (1994) Banting Lecture. Insulin action, diabetogenes, and the cause of type II diabetes. Diabetes 43: 1066-1084.

8. Robertson RP (1995) Antagonist: diabetes and insulin resistancephilosophy, science, and the multiplier hypothesis. Jrnl of Lab Clin Med 125: 560-564.

9. Dabelea D (1778) Prevalence of Type 1 and Type 2 Diabetes among Children and Adolescents. JAMA 311: 1778.

10. Pinhas-Hamiel O, Zeitler P (2005) The global spread of type 2 diabetes mellitus in children and adolescents. J Pediatr 146: 693-700. 
Citation: Abdulmoein E Al-Agha1, Mohammed A Al-Agha (2017) Severe Diabetic ketoacidosis in a Newly Diagnosed Child with Type 2 Diabetes Mellitus: A Case Report. J Diabetes Metab 8: 724. doi:10.4172/2155-6156.1000724

Page 4 of 4

11. Lori Laffel M, Britta PH, Svoren MD (2016) Epidemiology presentation, and diagnosis of type 2 diabetes mellitus in children and adolescentsUpToDate. Types 2 diabetes in children 8: 122.

12. George M, Jeha S, Morey MD Haymond W (2016) Clinical features and diagnosis of diabetic ketoacidosis in diabetes types \& selected. Diabetes Metabol 4: 11-16.

13. Edge JA, Hawkins MM, Winter DL, Dunger DB (2001) The risk and outcome of cerebral oedema developing during diabetic ketoacidosis. Arch Dis Child 85: 16-22.

14. Dunger DB, Dunger DB, Sperling MA, Acerini CL, Bohn DJ, Daneman D, et al. (2004) European Society for Paediatric Endocrinology/Lawson Wilkins Pediatric Endocrine Society Consensus Statement on Diabetic Ketoacidosis in Children and Adolescents. Pediatr 114: 533.
15. George M, Jeha S, Morey MD, Haymond W (2016) Cerebral edema in children with diabetic ketoacidosis. J Metab 11: 26-42.

16. Sapru A, Gitelman SE, Bhatia S, Dubin RF, Newman TB (2005) Prevalence and characteristics of type 2 diabetes mellitus in 9-18 year-old children with diabetic ketoacidosis. J Pediatr Endocrinol Metab 18: 865-872.

17. Scott CR, Smith JM, Cradock MM, Pihoker C (1997) Characteristics of youth-onset noninsulin-dependent diabetes mellitus and insulindependent diabetes mellitus at diagnosis. Pediatr 100: 84-91.

18. Glaser N (2001) Risk factors for cerebral edema in children with diabetic ketoacidosis. The Pediatric Emergency Medicine Collaborative Research Committee of the American Academy of Pediatrics. N Engl J Med 344: 264-269. 